\title{
CD59 Glycoprotein
}

National Cancer Institute

\section{Source}

National Cancer Institute. CD59 Glycoprotein. NCI Thesaurus. Code C95934.

CD59 glycoprotein (128 aa, $\sim 14 \mathrm{kDa}$ ) is encoded by the human CD59 gene. This protein is involved in the inhibition of the assembly of the membrane attack complex in the complement cascade. 